\title{
Analysis of Mathematical Modeling of PV Cell with Numerical Algorithm
}

\author{
Mohammed Rasheed*, Suha Shihab \\ Applied Sciences Department, University of Technology, Baghdad, Iraq \\ E-mail: rasheed.mohammed40@yahoo.com,10606@uotechnology.edu.iq
}

\begin{abstract}
In this paper, we exhibit two multi steps iterative algorithms for solving nonlinear equation. These two techniques are free from second derivative and per iteration; they only need six evaluations of the single-diode model function for solar cell of it is first derivative. Numerical examples investigate that both of the two techniques are more accurate, efficient and easy to use and more practical than of the two step methods. The absolute error values for all the algorithms have been demonstrated and compared.
\end{abstract}

Keywords: Two-Point Bracketing algorithm, Classic Chord algorithm, zeroes, three step method, solar cell

\section{Introduction}

Numerical analysis is the field of computer science and mathematics that implements, analyzes, and creates, techniques for solving numerically the examples of applied mathematics. Nowadays, based on a single diode model of solar cell several researchers have advanced many iterative techniques for solving nonlinear equations of it. These techniques can be assorted as one-step; two-step and three-step techniques. These techniques have been approached using Newton's method. At the present, many researchers has been displayed that these techniques can be employ to refinement some iterative techniques so as to solve nonlinear problems in the variant fields such as engineering and science ${ }^{[1,18]}$. We proposed and analyzed some iterative techniques without using second derivatives in order to solve the nonlinear equations of the solar cell (single diode) model using different values of the load resistance. There are many modes progressed on the progression the convergence of Newton's method, in order to attain lesser iterations than it ${ }^{[19,71]}$.

In this paper, a numerical iterative method Two-Point Bracketing algorithm based on Newton's and Classic Chord methods have been performed and demonstrated for solving the zeroes of nonlinear equations. It is described as the following steps: section 2 depicting the analytical sample of a single-diode design of the solar cell; section 3 demonstrate the root finding of Classic Chord method; while in section 4 Two-Point Bracketing algorithm has been described; section 5 results and discussion; section 6 conclusions of the accomplished results.

\section{Characteristics of single-diode solar cells equation}

In order to develop a clear describe of solar cells, the electrical model of the photovoltaic cell must first be clarified. The common model of a photovoltaic cell its representation as an ideal current source with a diode connects in parallel as shown in Figure 1.

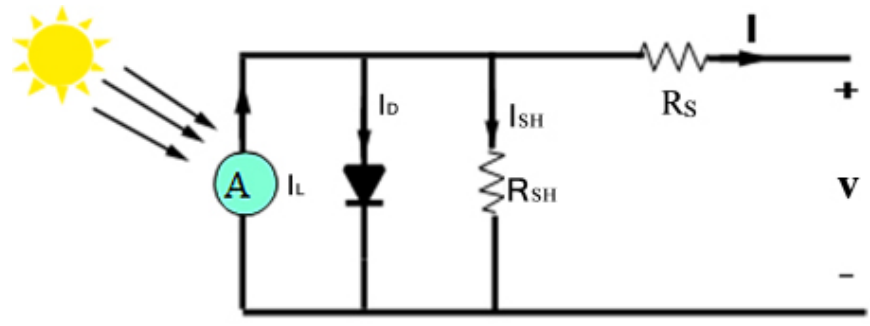

Figure 1. Circuit of a single-diode model 
The demonstration of the PV cell is illustrated by the nonlinear equations below based on Kiechoff's current law has been applied of the circuit

$$
\begin{aligned}
& I=I_{p h}-I_{D} \\
& I_{D}=I_{0}\left(e^{\frac{-V_{p v}}{n V} T}-1\right) \\
& I=I_{p h}-I_{0}\left(e^{\frac{-V_{p v}}{m V} T}-1\right)
\end{aligned}
$$

where:

$I_{p h}$ is the photocurrent $(A) ; I_{0}$ is reverse saturation current of the diode $(A) ; I$ and $V_{p v}$ are the delivered current and voltage, respectively $(V) ; V_{T}=\frac{k T}{q}=0.0259 \mathrm{~V}$ is thermic voltage $=27.5 \cong 26 \mathrm{mV}$ at $\left(T=25^{\circ} \mathrm{C}\right.$ Air-Mass $\left.=1.5\right) ; m$ is the recombination factor closeness to an ideal diode $(1<m<2), k$ is Boltzmann constant $=1.38 \times 10^{-23} \mathrm{~J} / \mathrm{K} ; T$ is $p$ - $n$ junction temperature $(K)$; $\mathrm{q}$ is the electron charge $=1.6 \times 10^{-19} \mathrm{C}$.

$$
\begin{aligned}
& I_{p h}=I_{\text {source }} \\
& I_{D}=I_{S} *\left(e^{\frac{V_{D}}{n V} T}-1\right)
\end{aligned}
$$

Merge Eq. 4 in Eq. 5 we get

$$
\begin{gathered}
I_{\text {source }}-10^{-12}\left(e^{\frac{-V}{1.2 * 0.026}}-1\right)=\frac{R}{V} \\
I_{p v}=\frac{V_{p v}}{R} ; \quad P_{p v}=I_{p v} \times V_{p v}
\end{gathered}
$$

where $I_{s}$ reverse saturation currentc $=10^{-12} \mathrm{~A}$. In parallel, $V_{D}=V_{p v}=V$

The current supplied by the solar cell is influenced by several factors, the most important of which are the temperature, the amount of light falling and the load resistance attached to the cell. According to Eq. 6 one can calculate $V$ of the cell numerically based on the first derivative of this equation.

\section{Classic Chord Method (CCM)}

For a given $x_{0}$, compute the approximate solution $x_{n+1}$ by the iterative scheme

Step 1: $x_{n+1}=x_{n}-m f\left(x_{n}\right)$ where $0<m f^{\prime}\left(x_{n}\right)<2$;

Step 2: $x_{n+1}=x_{n}-m_{n} f\left(x_{n}\right) m$ change at each iteration;

Step 3: $Z_{n+1}=x_{n+1}-\frac{x_{n+1}-x_{n}}{f\left(x_{n+1}\right)-f\left(x_{n}\right)} f\left(x_{n+1}\right)$

\section{Two-Point Bracketing Method (TPBM)}

Step 1: for a given $\left[a_{k}, b_{k}\right]$

Step 2: compute $c_{k}$ as follows $c_{k}=\frac{a_{k}+b_{k}}{2}, c_{k}$ is between $a_{k}$ and $b_{k}$. 
By assuming that $\varepsilon=10^{-9}$ as a tolerance; the following criteria is used for calculating the zeros

$$
\sigma=\left|x_{n+1}-x_{n}\right|<\varepsilon,\left|f\left(x_{n}\right)\right|<\varepsilon
$$

The model problem is to calculate the voltage and the power of the solar cell numerically, this idea is achieved by applying Kiechoff's current law on the circuit of a single-diode model and the obtained results are Eqns. 6 and 7.

\section{Results and discussion}

Consider the Eq. 6 we start with $x_{0}=1$; the results obtained by Classic Chord Method (CCM) and proposed method (TPBM) is shown in Tables. In Table 1 numerical results of Eqs. 6 and 7 for CCM and TPBM. The results are listed in this table when the load resistance $R=1$; and Figure 3 exhibits the obtained solutions of the study result.

Table 1. Comparison with CCM and TPBM

\begin{tabular}{cccc}
\hline Iterations & $V_{p v}-\mathrm{CCM}$ & $I_{p v}-\mathrm{CCM}$ & $P_{p v}-\mathrm{CCM}$ \\
\hline 1 & 0.956342897 & 0.956342897 & 0.914591738 \\
2 & 0.935676402 & 0.935676402 & 0.875490329 \\
3 & 0.924881651 & 0.924881651 & 0.855406068 \\
4 & 0.922517679 & 0.922517679 & 0.851038869 \\
5 & 0.922423278 & 0.922423278 & 0.850864704 \\
6 & 0.922423135 & 0.922423135 & 0.850864439 \\
7 & 0.922423135 & 0.922423135 & 0.850864439 \\
\hline
\end{tabular}

\begin{tabular}{cccccc}
\hline Iterations & $V_{p v}-\mathrm{TPBM}$ & $I_{p v}-\mathrm{TPBM}$ & $P_{p v}-\mathrm{TPBM}$ & $\varepsilon-\mathrm{CCM}$ & $\varepsilon$-TPBM \\
\hline 1 & 0.94600965 & 0.94600965 & 0.894934257 & 0.033919763 & 0.023586515 \\
2 & 0.930279026 & 0.930279026 & 0.865419067 & 0.013253267 & 0.007855892 \\
3 & 0.923699665 & 0.923699665 & 0.853221071 & 0.002458516 & 0.001276531 \\
4 & 0.922470479 & 0.922470479 & 0.850951784 & $9.45447 \mathrm{E}^{-05}$ & $4.73443 \mathrm{E}^{-05}$ \\
5 & 0.922423206 & 0.922423206 & 0.850864572 & $1.43773 \mathrm{E}^{-07}$ & $7.18866 \mathrm{E}^{-08}$ \\
6 & 0.922423135 & 0.922423135 & 0.850864439 & $3.33178 \mathrm{E}^{-13}$ & 0 \\
7 & & & & 0 & 0 \\
\hline
\end{tabular}
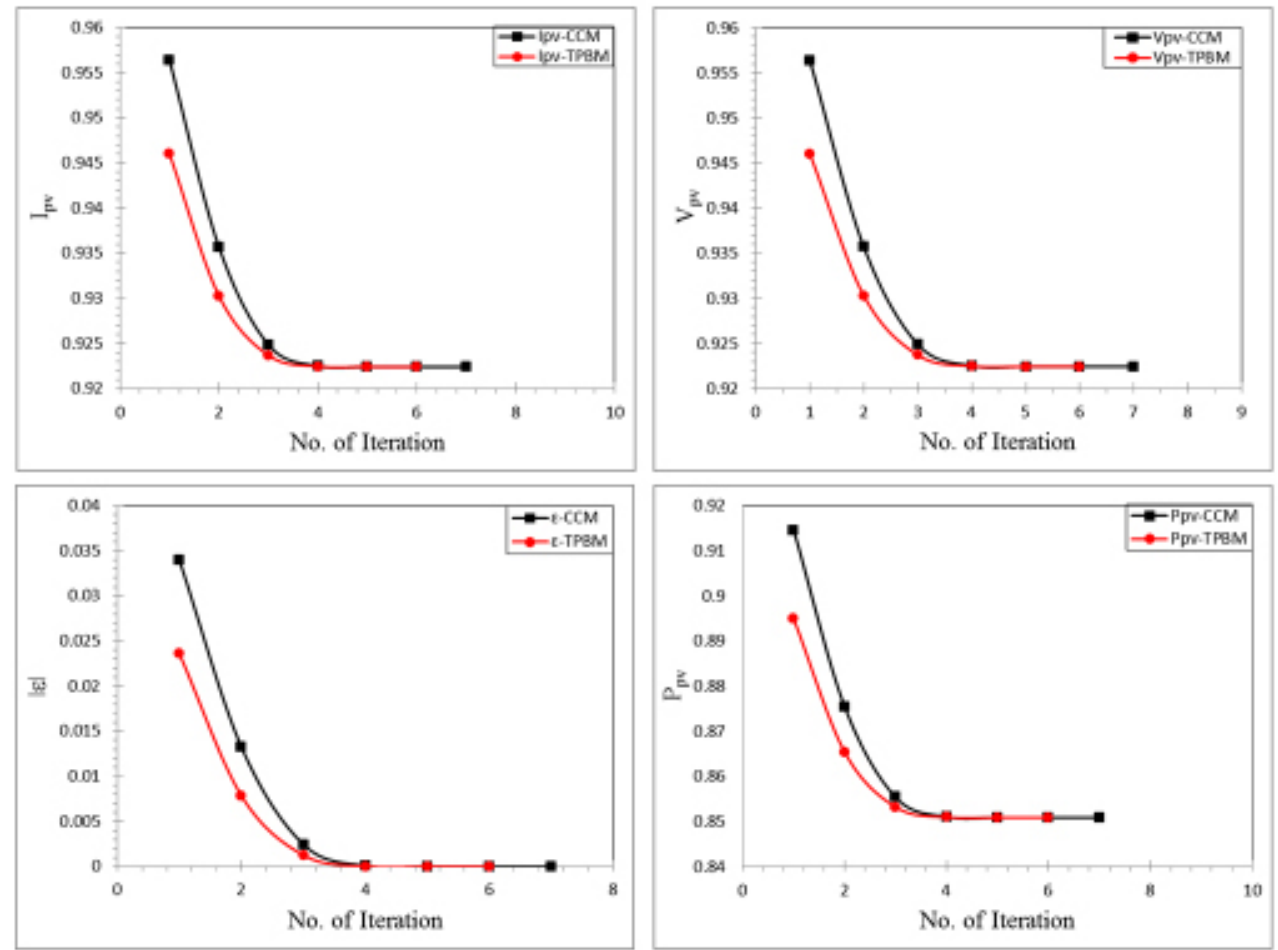

Figure 3. comparison of numerical and absolute error for Eqs. 6 and 7 
In Table 2 numerical results of Eqs. 6 and 7 for CCM and TPBM. The results are listed in this table when the load resistance $R=2$; and Figure 4 exhibits the obtained solutions of the study result.

Table 2. Comparison with CCM and TPBM

\begin{tabular}{cccc}
\hline Iterations & $V_{p v}-\mathrm{CCM}$ & $I_{p v}-\mathrm{CCM}$ & $P_{p v}-\mathrm{CCM}$ \\
\hline 1 & 0.955509809 & 0.477754904 & 0.456499497 \\
2 & 0.933452268 & 0.466726134 & 0.435666569 \\
3 & 0.920708719 & 0.46035436 & 0.423852273 \\
4 & 0.917245199 & 0.4586226 & 0.420669378 \\
5 & 0.917036095 & 0.458518047 & 0.4204776 \\
6 & 0.917035382 & 0.458517691 & 0.420476946 \\
7 & 0.917035382 & 0.458517691 & 0.420476946 \\
\hline
\end{tabular}

\begin{tabular}{cccccc}
\hline Iterations & $V_{p v}-\mathrm{TPBM}$ & $I_{p v}-\mathrm{TPBM}$ & $P_{p v}-\mathrm{TPBM}$ & $\varepsilon-\mathrm{CCM}$ & $\varepsilon-\mathrm{TPBM}$ \\
\hline 1 & 0.944481039 & 0.472240519 & 0.446022216 & 0.038474426 & 0.027445656 \\
2 & 0.927080494 & 0.463540247 & 0.429739121 & 0.016416886 & 0.010045111 \\
3 & 0.918976959 & 0.45948848 & 0.422259326 & 0.003673337 & 0.001941577 \\
4 & 0.917140647 & 0.458570324 & 0.420573483 & 0.000209817 & 0.000105265 \\
5 & 0.917035739 & 0.458517869 & 0.420477273 & $7.12519 \mathrm{E}^{-07}$ & $3.5626 \mathrm{E}^{-07}$ \\
6 & 0.917035382 & 0.458517691 & 0.420476946 & $8.24774 \mathrm{E}^{-12}$ & 0 \\
7 & & & & 0 & 0 \\
\hline
\end{tabular}
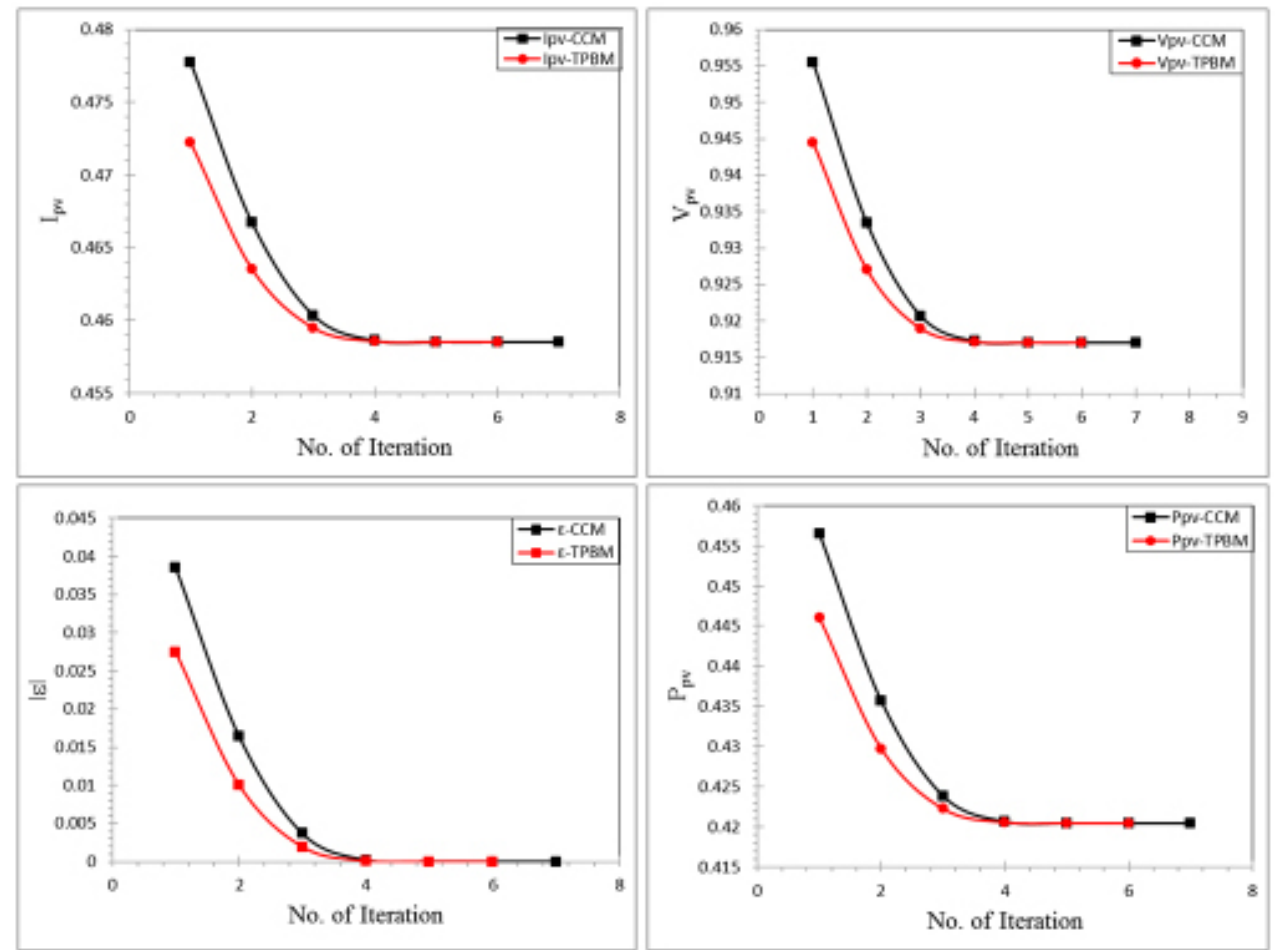

Figure 4. comparison of numerical and absolute error for Eqs. 6 and 7 
In Table 3 numerical results of Eqs. 6 and 7 for CCM and TPBM. The results are listed in this table when the load resistance.; $R=3$ and Figure 5 exhibits the obtained solutions of the study result.

Table 3. Comparison with CCM and TPBM

\begin{tabular}{cccc}
\hline Iterations & $V_{p v}-\mathrm{CCM}$ & $I_{p v}-\mathrm{CCM}$ & $P_{p v}-\mathrm{CCM}$ \\
\hline 1 & 0.954668501 & 0.318222834 & 0.303797316 \\
2 & 0.931130761 & 0.31037692 & 0.289001498 \\
3 & 0.916050375 & 0.305350125 & 0.279716096 \\
4 & 0.91089377 & 0.303631257 & 0.27657582 \\
5 & 0.910407299 & 0.3034691 & 0.276280483 \\
6 & 0.910403374 & 0.303467791 & 0.276278101 \\
7 & 0.910403374 & 0.303467791 & 0.276278101 \\
\hline
\end{tabular}

\begin{tabular}{cccccc}
\hline Iterations & $V_{p v}-\mathrm{TPBM}$ & $I_{p v}-\mathrm{TPBM}$ & $P_{p v}-\mathrm{TPBM}$ & $\varepsilon-\mathrm{CCM}$ & $\varepsilon-\mathrm{TPBM}$ \\
\hline 1 & 0.942899631 & 0.314299877 & 0.296353238 & 0.044265127 & 0.032496257 \\
2 & 0.923590568 & 0.307863523 & 0.284339846 & 0.020727387 & 0.013187194 \\
3 & 0.913472073 & 0.307863523 & 0.278143742 & 0.005647001 & 0.003068698 \\
4 & 0.910650534 & 0.303550178 & 0.276428132 & 0.000490396 & 0.00024716 \\
5 & 0.910405337 & 0.303468446 & 0.276279292 & $3.92473 \mathrm{E}^{-06}$ & $1.96237 \mathrm{E}^{-06}$ \\
6 & 0.910403374 & 0.303467791 & 0.276278101 & $2.53289 \mathrm{E}^{-10}$ & 0 \\
7 & & & & 0 & 0 \\
\hline
\end{tabular}
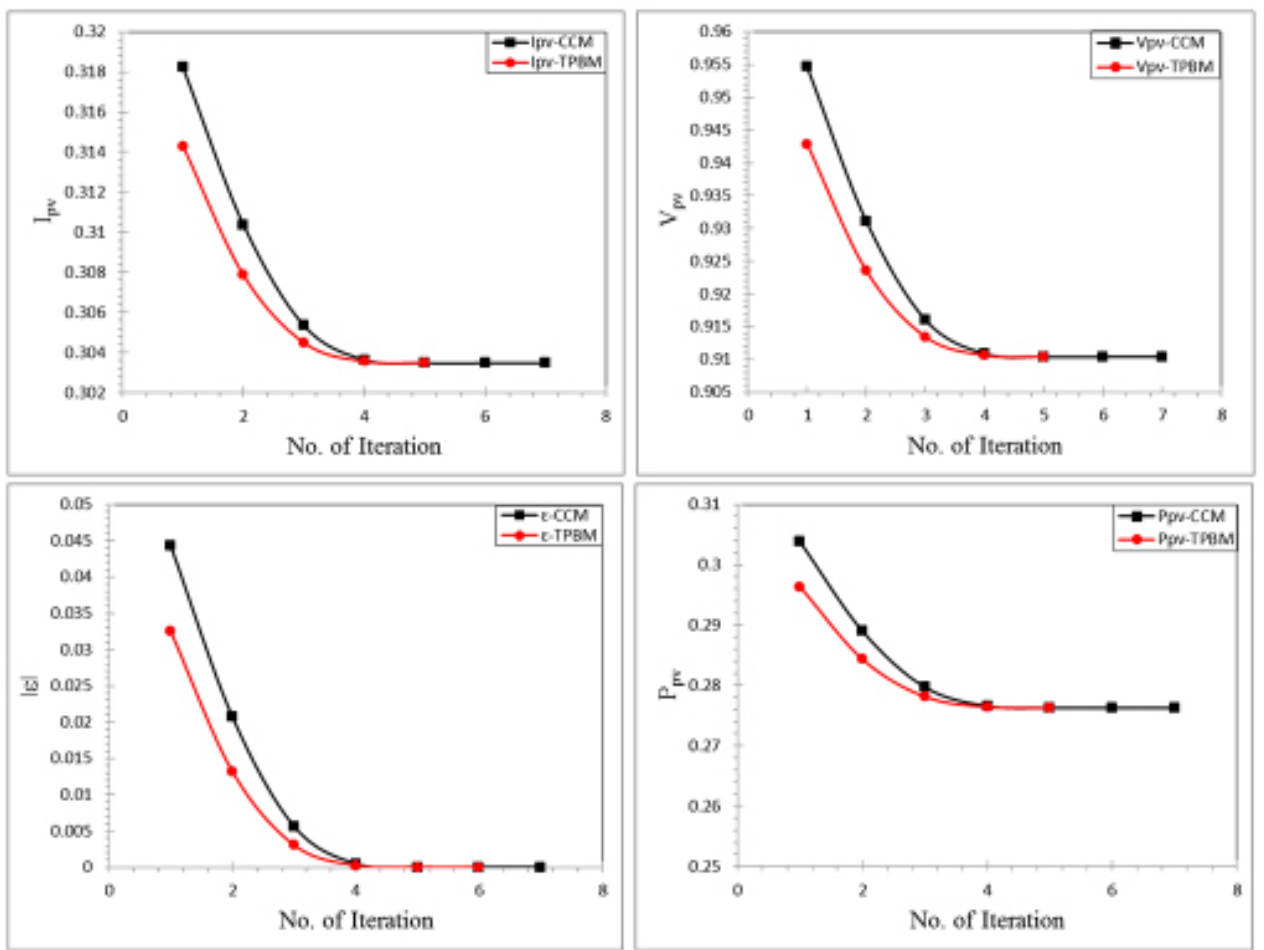

Figure 5. comparison of numerical and absolute error for Eqs. 6 and 7 
In Table 4 numerical results of Eqs. 6 and 7 for CCM and TPBM. The results are listed in this table when the load resistance $R=4$; and Figure 6 exhibits the obtained solutions of the study result.

Table 4. Comparison with CCM and TPBM

\begin{tabular}{cccc}
\hline Iterations & $V_{p v}-\mathrm{CCM}$ & $I_{p v}-\mathrm{CCM}$ & $P_{p v}-\mathrm{CCM}$ \\
\hline 1 & 0.953818908 & 0.238454727 & 0.227442627 \\
2 & 0.928705897 & 0.232176474 & 0.215623661 \\
3 & 0.910811452 & 0.227702863 & 0.207394375 \\
4 & 0.902978861 & 0.225744715 & 0.203842706 \\
5 & 0.901765899 & 0.225441475 & 0.203295434 \\
6 & 0.901740613 & 0.225435153 & 0.203284033 \\
7 & 0.901740602 & 0.22543515 & 0.203284028 \\
8 & 0.901740602 & 0.22543515 & 0.203284028 \\
\hline
\end{tabular}

\begin{tabular}{cccccc}
\hline Iterations & $V_{p v}-\mathrm{TPBM}$ & $I_{p v}-\mathrm{TPBM}$ & $P_{p v}-\mathrm{TPBM}$ & $\varepsilon-\mathrm{CCM}$ & $\varepsilon-\mathrm{TPBM}$ \\
\hline 1 & 0.941262402 & 0.235315601 & 0.221493728 & 0.052078306 & 0.0395218 \\
2 & 0.919758674 & 0.229939669 & 0.211489005 & 0.026965295 & 0.018018072 \\
3 & 0.906895156 & 0.226723789 & 0.205614706 & 0.00907085 & 0.005154554 \\
4 & 0.90237238 & 0.225593095 & 0.203568978 & 0.001238259 & 0.000631778 \\
5 & 0.901753256 & 0.225438314 & 0.203289734 & $2.52971 \mathrm{E}^{-05}$ & $1.26539 \mathrm{E}^{-05}$ \\
6 & 0.901740607 & 0.225435152 & 0.203284031 & $1.07408 \mathrm{E}^{-08}$ & $5.37042 \mathrm{E}^{-09}$ \\
7 & 0.901740602 & 0.22543515 & 0.203284028 & $1.9984 \mathrm{E}-15$ & 0 \\
8 & & & & & 0 \\
\hline
\end{tabular}
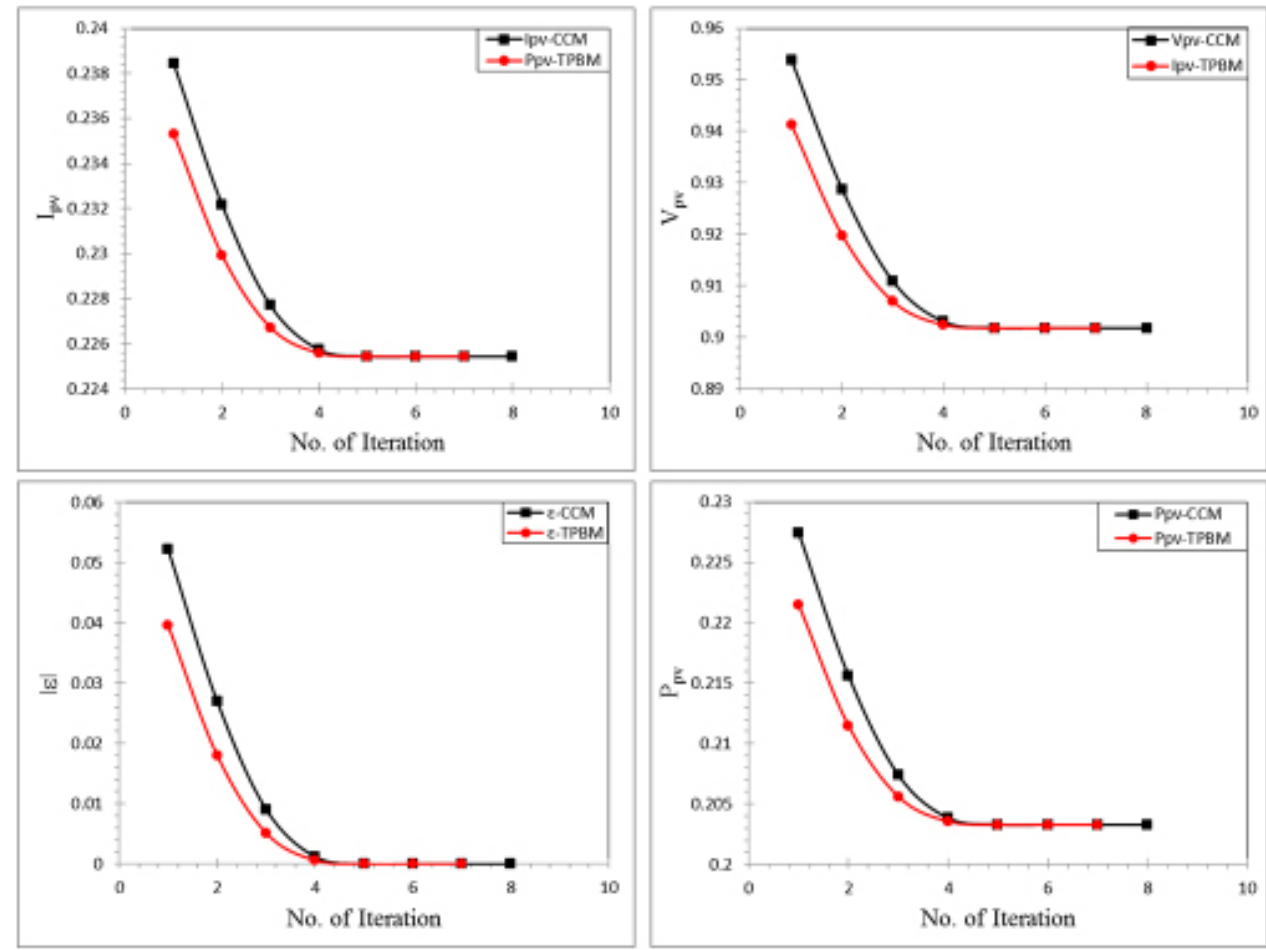

Figure 6. comparison of numerical and absolute error for Eqs. 6 and 7 
In Table 5 numerical results of Eqs. 6 and 7 for CCM and TPBM. The results are listed in this table when the load resistance $R=5$; and Figure 7 exhibits the obtained solutions of the study result.

Table 5. Comparison with CCM and TPBM

\begin{tabular}{cccc}
\hline Iterations & $V_{p v}-\mathrm{CCM}$ & $I_{p v}-\mathrm{CCM}$ & $P_{p v}-\mathrm{CCM}$ \\
\hline 1 & 0.952960959 & 0.190592192 & 0.181626918 \\
2 & 0.926171251 & 0.18523425 & 0.171558637 \\
3 & 0.904871952 & 0.18097439 & 0.16375865 \\
4 & 0.89266728 & 0.178533456 & 0.159370975 \\
5 & 0.889306005 & 0.177861201 & 0.158173034 \\
6 & 0.889093511 & 0.177818702 & 0.158097454 \\
7 & 0.889092715 & 0.177818543 & 0.158097171 \\
8 & 0.889092715 & 0.177818543 & 0.158097171 \\
\hline
\end{tabular}

\begin{tabular}{cccccc}
\hline Iterations & $V_{p v}-\mathrm{TPBM}$ & $I_{p v}-\mathrm{TPBM}$ & $P_{p v}-\mathrm{TPBM}$ & $\varepsilon$-CCM & $\varepsilon$-TPBM \\
\hline 1 & 0.939566105 & 0.187913221 & 0.176556893 & 0.063868245 & 0.05047339 \\
2 & 0.915521602 & 0.18310432 & 0.167635961 & 0.037078536 & 0.026428887 \\
3 & 0.898769616 & 0.179753923 & 0.161557365 & 0.015779238 & 0.009676902 \\
4 & 0.890986643 & 0.178197329 & 0.15877144 & 0.003574566 & 0.001893928 \\
5 & 0.889199758 & 0.177839952 & 0.158135242 & 0.00021329 & 0.000107043 \\
6 & 0.889093113 & 0.177818623 & 0.158097313 & $7.96312 \mathrm{E}^{-07}$ & $3.98156 \mathrm{E}^{-07}$ \\
7 & 0.889092715 & 0.177818543 & 0.158097171 & $1.11464 \mathrm{E}^{-11}$ & 0 \\
8 & & & & 0 & 0 \\
\hline
\end{tabular}
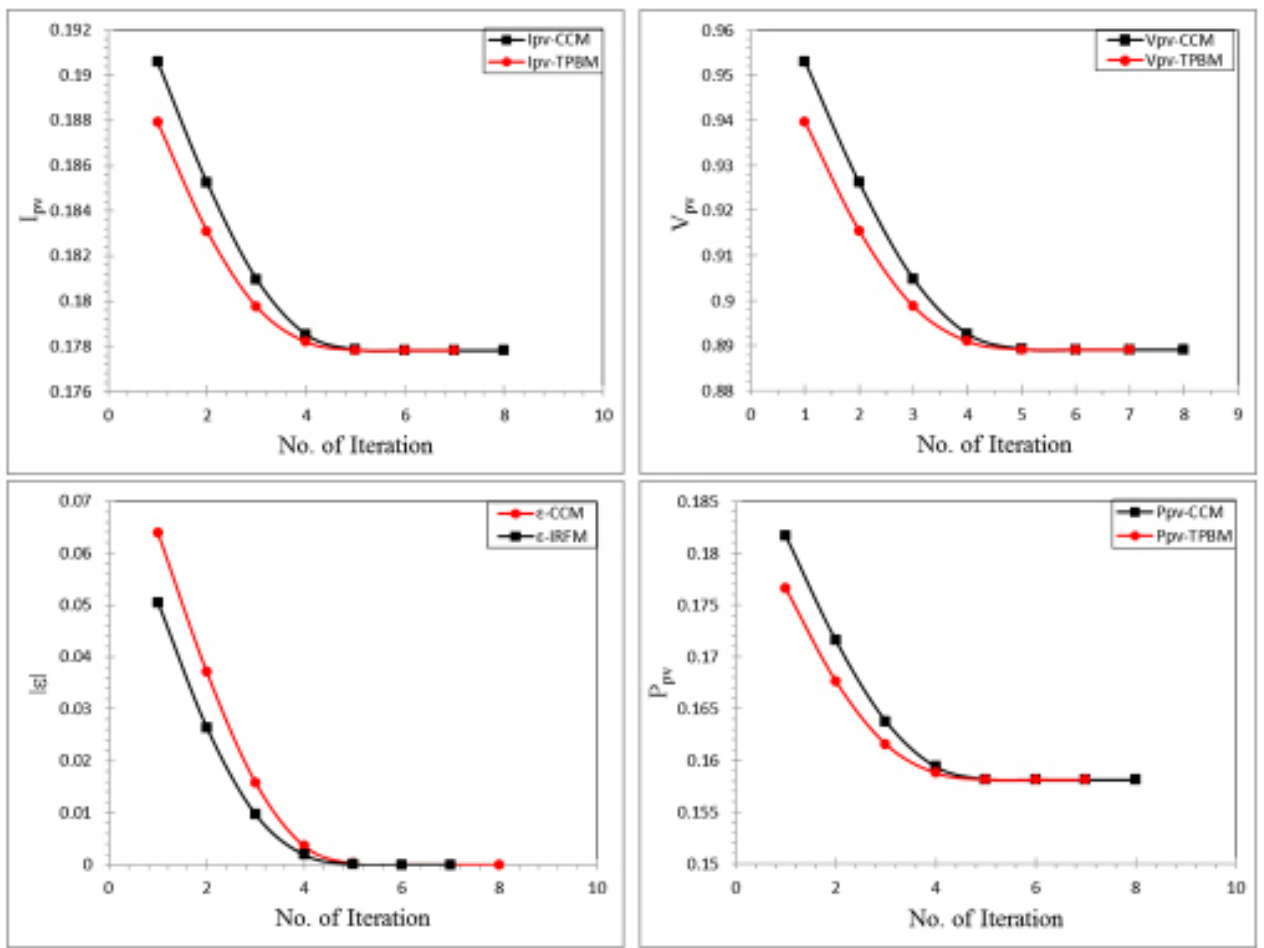

Figure 7. comparison of numerical and absolute error for Eqs. 6 and 7

Thus from the Tables 1, 2, 3, 4 and 5 the main observations are, first the present algorithm picks a lesser number of iterations than the other method, second the results in the last column of these Tables, shows the absolute error's value is least for of the proposed algorithm. Therefore, the proposed technique is faster than the other method. In addition, only 6 and 7 iterations have been needed when using the proposed methods; "Classical Chord" and "two-point bracketing" respectively, while using Newton method we need nine iterations as indicated in the Tables 1, 2, 3, 4 and 5. 


\section{Conclusion}

In this paper, we exhibit two iterative techniques for solving nonlinear equations of single diode model for solar cell with various values of load resistance. We proved that the acquired results from the proposed method Two-Point Bracketing algorithm are comparable with the Newton's and CCM methods in all cases. Several numerical examples detect that the new proposed method is more accurate, efficient and easy to use with lesser iterations compared with other methods. Numerical computations recorded here have been carried out in MATLAB program the stopping criterion has been taken as $\left|x_{n+1}-\alpha\right|+\left|f\left(x_{n+1}\right)\right|<10^{9}$.

\section{References}

[1] Shihab SN, Sarhan MA. Convergence analysis of shifted fourth kind chebyshev wavelets. IOSR journal of mathematics. 2014; 10(2): 54-8.

[2] Al-Rawi SN. Numerical solution of integral equations using taylor series. Journal of the College of Education. 1992; 5: 51-60.

[3] SHIHAB SN, Sarhan MA. New operational matrices of shifted fourth chebyshev wavelets. Elixir International Journal-Applied Mathematics. 2014; 69(1): 23239-23244.

[4] Delphi M, SHIHAB S. Operational matrix basic spline wavelets of derivative for linear optimal control problem. Electronics Science Technology and Application. 2019; 6(2): 18-24.

[5] Al-Rawi SN. On the solution of certain fractional integral equations. kirkuk university journal for scientific studies. 2006; 1(2): 125-136.

[6] Dephi M, SHIHAB S. Modified iterative algorithm for solving optimal control problems. Open Science Journal of Statistics and Application. 2019; 6(2): 20.

[7] Shihab SN, Naif TN. On the orthonormal bernstein polynomial of order eight. Open Science Journal of Mathematics and Application. 2014; 2(2): 15-19.

[8] Delphi M, SHIHAB S. State parametrization casic spline functional for trajectory optimization. The journal of Nature life and Applied Sciences. 2019; 3(4). Available from: doi: https://doi.org/10.26389/AJSRP.S270519.

[9] Delphi M, SHIHAB S. Modified basic spline multiscaling and wavelets algorithms for optimal control problems. Iraq: University of Technology, Baghdad; 2019.

[10] Shihab SN, Naif TN. Direct methods based on orthonormal bernstein polynomials for solving optimal control problems. Iraq: University of Technology, Baghdad; 2014.

[11] Shihab SN, Sarhan MA. Numerical solution of variational calculus using chebyshev wavelet method. Iraq: University of Al-Mustansiriyah University, Baghdad; 2014.

[12] Shihab SN, Falah AH. Efficient numerical algorithms for the optimal control problem. Iraq: University of AlMustansiriyah University, Baghdad; 2014.

[13] Shihab SN, Al-Janabi ASAR. On the Numerical solution for solving some continuous optimal control problems. Iraq: University of Technology, Baghdad; 2005.

[14] Al-Faour O, Shihab SN, Al-Saleni BF. Multistep methods for solving nonlinear integral equations. Journal of the College of Basic Education. 2001; 12 (2).

[15] Al-Faour O, Shihab SN, Al-Nasser RH. Expansion method for solving volterra equations. Journal of Babylon University. 2000; 7(3): 1355-1362.

[16] Al-Faour O, Al-Ani FID, Al-Rawi S. N. Numerical evaluation of fourier transformation using orthogonal functions. Engineering and Technology Journal. 2000; 17 (7).

[17] Al-Ani FID, Al-Faour O, Al-Rawi SN. Numerical solution of variational calculus using chebyshev wavelet method. Journal of Al-rafidian University. 1997; 2: 1-10.

[18] SHIHAB S, Dephi M. Direct iterative algorithm for solving optimal control problems using B-spline polynomials. Emirates Journal for Engineering Research. 2019; 24(4): 2.

[19] Rasheed MS. Study of the effects of acidic solutions on the physical properties of polymeric materials superimposed. Al-Mustansiriyah Journal of Science. 2012; 13(49): 6.

[20] Rasheed MS, Mahde HS. Electronic combination lock design using remote control. Journal of the College of Basic Education. 2012; 18(75): 265-280.

[21] Rasheed MS, Mohammed AN. Design of a laser based free space communication system. Germany: LAP LAMBERT Academic Publishing; 2012.

[22] Rasheed MS. Approximate solutions of barker equation in parabolic orbits. Engineering \& Technology Journal. 2010; 28(3): 492-499.

[23] Rasheed MS, An improved algorithm for the solution of kepler's equation for an elliptical orbit. Engineering \& 
Technology Journal. 2010; 28(7): 1316-1320.

[24] Rasheed MS. Acceleration of predictor corrector halley method in astrophysics application. International Journal of Emerging Technologies in Computational and Applied Sciences. 2012; 1(2): 91-94.

[25] Rasheed MS. Fast procedure for solving two-body problem in celestial mechanic. International Journal of Engineering, Business and Enterprise Applications. 2012; 1(2): 60-63.

[26] Rasheed MS. Solve the position to time equation for an object travelling on a parabolic orbit in celestial mechanics. Diyala journal for pure sciences. 2013; 9(4): 31-38.

[27] Rasheed MS. Comparison of starting values for implicit iterative solutions to hyperbolic orbits equation. International Journal of Software and Web Sciences (IJSWS). 2013; 1(2): 65-71.

[28] Rasheed MS. On solving hyperbolic trajectory using new predictor-corrector quadrature algorithms. Baghdad Science Journal. 2014; 11(1): 186-192.

[29] Rasheed MS. Modification of three order methods for solving satellite orbital equation in elliptical motion. Journal of university of Anbar for Pure science. 2020.

[30] Rasheed M, Barillé R. Room temperature deposition of $\mathrm{ZnO}$ and $\mathrm{Al}: \mathrm{ZnO}$ ultrathin films on glass and PET substrates by DC sputtering technique. Optical and Quantum Electronics. 2017; 49(5): 1-14.

[31] Rasheed M, Barillé R. Optical constants of DC sputtering derived ITO, $\mathrm{TiO}_{2}$ and $\mathrm{TiO}_{2}: \mathrm{Nb}$ thin films characterized by spectrophotometry and spectroscopic ellipsometry for optoelectronic devices. Journal of Non-Crystalline Solids. 2017; 476: 1-14.

[32] Rasheed M, Barillé R. Comparison the optical properties for $\mathrm{Bi}_{2} \mathrm{O}_{3}$ and $\mathrm{NiO}$ ultrathin films deposited on different substrates by DC sputtering technique for transparent electronics. Journal of Alloys and Compounds. 2017; 728: 11861198.

[33] Saidani T, Zaabat M, Aida MS, et al. Influence of precursor source on sol-gel deposited $\mathrm{ZnO}$ thin films properties. Journal of Materials Science: Materials in Electronics. 2017; 28(13): 9252-9257.

[34] Guergouria K, Boumezoued A, Barille R, et al. ZnO nanopowders doped with bismuth oxide, from synthesis to electrical application. Journal of Alloys and Compounds. 2019; 791: 550-558.

[35] Bouras D, Mecif A, Barillé R, et al. Cu:ZnO deposited on porous ceramic substrates by a simple thermal method for photocatalytic application. Ceramics International. 2018; 44(17): 21546-21555.

[36] Saidi W, Hfaidh N, Rasheed M, et al. Effect of $\mathrm{B}_{2} \mathrm{O}_{3}$ addition on optical and structural properties of $\mathrm{TiO}_{2}$ as a new blocking layer for multiple dye sensitive solar cell application (DSSC). RSC Advances. 2016; 6(73): 68819-68826.

[37] AUKŠTUOLIS A, Girtan M, Mousdis GA, et al. Measurement of charge carrier mobility in perovskite nanowire films by photo-CELIV method. Proceedings of the Romanian Academy Series a-Mathematics Physics Technical Sciences Information Science. 2017; 18(1): 34-41.

[38] Dkhilalli F, Megdiche S, Guidara K, et al. AC conductivity evolution in bulk and grain boundary response of sodium tungstate $\mathrm{Na}_{2} \mathrm{WO}_{4}$. Ionics. 2018; 24(1): 169-180.

[39] Dkhilalli F, Borchani SM, Rasheed M, et al. Structural, dielectric and optical properties of the zinc tungstate $\mathrm{ZnWO}_{4}$ compound. Journal of Materials Science: Materials in Electronics. 2018; 29(8): 6297-6307.

[40] Dkhilalli F, Borchani SM, Rasheed M, et al. Characterizations and morphology of sodium tungstate particles. Royal Society open science. 2018; 5(8): 1-12.

[41] Enneffati M, Louati B, Guidara K, et al. Crystal structure characterization and AC electrical conduction behavior of sodium cadmium orthophosphate. Journal of Materials Science: Materials in Electronics. 2018; 29(1): 171-179.

[42] Kadri E, Krichen M, Mohammed R, et al. Electrical transport mechanisms in amorphous silicon/crystalline silicon germanium heterojunction solar cell: impact of passivation layer in conversion efficiency. Optical and Quantum Electronics. 2016; 48(12): 1-15.

[43] Kadri E, Messaoudi O, Krichen M, et al. Optical and electrical properties of SiGe/Si solar cell heterostructures: Ellipsometric study. Journal of Alloys and Compounds. 2017; 721: 779-783.

[44] Kadri E, Dhahri K, Zaafouri A, et al. Ac conductivity and dielectric behavior of a-Si:H/c-Si $-\mathrm{Si}_{1-\mathrm{y}} \mathrm{Ge}_{\mathrm{y}} / \mathrm{p}-\mathrm{Si}$ thin films synthesized by molecular beam epitaxial method. Journal of Alloys and Compounds. 2017; 705: 708-713.

[45] Azaza NB, Elleuch S, Rasheed M, et al. 3-(p-nitrophenyl) Coumarin derivatives: Synthesis, linear and nonlinear optical properties. Optical Materials. 2019; 96: 109328.

[46] Enneffati M, Rasheed M, Louati B, et al. Morphology, UV-visible and ellipsometric studies of sodium lithium orthovanadate. Optical and Quantum Electronics. 2019; 51(9): 299.

[47] RASHEED M, Sarhan MA. Solve and implement the main equations of photovoltaic cell parameters using visual studio program. Insight-Mathematics. 2019; 1(1): 18-26.

[48] Rasheed M, Sarhan MA. Characteristics of solar cell outdoor measurements using fuzzy logic method. InsightMathematics. 2019; 1(1): 1-8. 
[49] RASHEED M, Sarhan MA. Measuring the solar cell parameters using fuzzy set technique. Insight-Electronic. 2019; 1(1): $1-9$.

[50] RASHEED M. Linear programming for solving solar cell parameters. Insight-Electronic. 2019; 1(1): 10-16.

[51] RASHEED M. Investigation of solar cell factors using fuzzy set technique. Insight-Electronic. 2019; 1(1): 17-23.

[52] RASHEED M, Barille R. Development and characterization of single and multilayer thin films for optoelectronics application. France: University of Angers; 2017.

[53] RASHEED M, SHIHAB S. Analytical modeling of solar cells. Insight Electronics. 2019; 1(2): 1-9.

[54] RASHEED M, SHIHAB S. Modeling and simulation of solar cell mathematical model parameters determination based on different methods. Insight Mathematics. 2019; 1(1): 1-16.

[55] RASHEED M, SHIHAB S. Parameters estimation for mathematical model of solar cell. Electronics Science Technology and Application. 2019; 6(1): 20-28.

[56] OUDA EH, SHIHAB S, RASHEED M. Boubaker wavelets functions for solving higher order integro-differential equation. Journal of Southwest Jiaotong University. 2020; 55(2). Available from: doi: https://doi.org/10.35741/ issn.0258-2724.55.2.2.

[57] SARHAN AM, SHIHAB S, RASHEED M. A new boubaker wavelets operational matrix of integration. Journal of Southwest Jiaotong University. 2020; 55(2). Available from: doi: https://doi.org/10.35741/issn.0258-2724.55.2.3.

[58] Abdulrahman AA, RASHEED M, SHIHAB S. Discrete Hermite Wavelet Filters (DHWF) with prove mathematical aspects. Journal of Southwest Jiaotong University. 2020; 55(2). Available from: doi: https://doi.org/10.35741/ issn.0258-2724.55.2.35.

[59] RASHEED M, Abdulrahman AA, SHIHAB S. Discrete chebyshev wavelet transformation with image processing. Journal of Southwest Jiaotong University. 2020; 55(2). Available from: doi: https://doi.org/10.35741/issn.02582724.55.2.26.

[60] Abbas MM, RASHEED M. Solid state reaction synthesis and characterization of Al doped $\mathrm{TiO}_{2}$ nanomaterials. Journal of Southwest Jiaotong University. 2020; 55(2).

[61] SARHAN AM, SHIHAB S, RASHEED M. On the properties of two dimensional normalized boubaker polynomials. Journal of Southwest Jiaotong University. 2020; 5(3).

[62] Aziz SH, RASHEED M, SHIHAB S. New properties of modified second kind chebyshev polynomials. Journal of Southwest Jiaotong University. 2020; 5(3).

[63] Mitlif RJ, RASHEED M, SHIHAB S. An optimal algorithm for fuzzy transportation problem. Journal of Southwest Jiaotong University. 2020; 5(3).

[64] Kashem BE, Ouda EH, Aziz SH, et al. Some results for orthonormal boubaker polynomials with application. Journal of Southwest Jiaotong University. 2020; 5(3).

[65] Mohammedali MN, Sabri RI, RASHEED M, et al. Some results on g-normed linear space. Journal of Southwest Jiaotong University. 2020; 5(4).

[66] Sabri RI, Mohammedali MN, RASHEED M, et al. Compactness of soft fuzzy metric space. Journal of Southwest Jiaotong University. 2020; 5(4).

[67] Rasheed M, Shihab S. Numerical techniques for solving parameters of solar cell. Applied Physics. 2020; 3(2): 16-27. Available from: doi: https://doi.org/10.31058/j.ap.2020.31002.

[68] Yu F, Liang Y, Sun X, et al. Modelling solar cells' s-shaped IV characteristics with an analytical solution to lumpedparameter equivalent circuit model. Solar Energy. 2020; 202: 498-506.

[69] Herbazi R, Amechnoue K, Khouya A, et al. Investigation of photovoltaic output characteristics with iterative methods. Procedia Manufacturing. 2019; 1(32): 794-801.

[70] Yu F, Huang G, Xu C. An explicit method to extract fitting parameters in lumped-parameter equivalent circuit model of industrial solar cells. Renewable Energy. 2020; 1(146): 2188-2198.

[71] Abdulrazzaq AK, Bognár G, Plesz B. Evaluation of different methods for solar cells/modules parameters extraction. Solar Energy. 2020; 196: 183-195. 